$\left[\begin{array}{llll}\text { 衛 } & \text { 生 } & \text { 化 } & \text { 学 } \\ 36(2) & \text { EISEI } & \text { KAGAKU } & \\ 36 & -138 & (1990)\end{array}\right]$

化粧品用赤色 201 号の副色素の分析とその変異原性に関する研究

宮越 護，早川ゆみ子，永田 稔，永山富雄

東京薬科大学

\title{
Studies on the Analysis of the Subsidiary Dyes of Lithol Rubine B and Their Mutagenicities
}

Mamoru Miyagoshi, Yumiko Hayakawa, Minoru Nagata and Tomio Nagayama

Tokyo College of Pharmacy, 1432-1, Horinouchi, Hachioji, Tokyo 192-03, Japan

(Received September 20, 1989)

Five subsidiary dyes of Lithol Rubine B (C.I. 15850) were synthesized to clear the chemical structures of mutagenic impurities in the commercial cosmetic Lithol Rubine B. Their analyses by HPLC were investigated and the mutagenic activities examined by Ames test by using Salmonella typhimurium TA 98 and TA 100.

The subsidiary dyes and Lithol Rubine B were completely separated by the gradient HPLC analysis by using an Inertsil ODS column and acetonitrile-water-formic acid system as a mobile phase. The subsidiary dyes showed no mutagenic activities to $S$. typhimurium with or without S9mix.

These results suggest that the mutagenic activities may not be due to the subsidiary dyes but to some reaction intermediates in the synthetic process of Lithol Rubine B.

Keywords - Lithol Rubine B ; commercial azo-dye; mutagenicity ; Ames test; mutagenic impurity; subsidiary dye; by-product; reaction intermediate; azo-dye separation; gradient HPLC

\section{緒}

\section{言}

著者らはこれまでに衛生化学的見地から，化粧品 用色素の内, アゾ系色素を中心に検討を加え, ${ }^{1}$ 赤色 225 号及び赤色 501 号に関しては，市販色素の変異 原性が残存する原料物質に起因することを解明し た. ${ }^{1 b)}$ 赤色 201 号に関しては，色素合成反応時にお けるジアゾ液〔A〕とカップリング液〔B〕の反応量 の比率 (モル比) $3 ： 2$ 及び $6 ： 5$ 等のように (A]> B B とした時にのみ変異原性物質が生成する ことを確認した。なお，〔A]> $[\mathrm{B}]$ で合成した赤色 201 号粗結晶の酢酸エチル抽出物及び市販色素酢酸 エチル抽出物中には着色物質も含めて多数の夾雑物

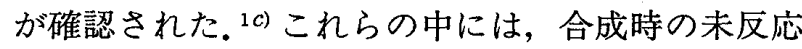
原料 - 反応中間体 - 副色素（原料やその類縁物質か ら副生する色素) 等の存在が推察される.

ところで，これまでに夾雑物が人体に对して問題 になった例として，赤色 219 号中に夾雑した副色素
の1-フェニルアゾー2 -ナフトールによる接触皮膚炎 に関する報告がある。 ${ }^{2)}$ 一方，著者らの市販赤色 505 号の HPLC 分析の結果では, 通常構造式の示されて いる 2,4 -ジメチル置換体以外に 2,5 及び 2,6 置換 体が混在する市販品が存在することを見出だしてい る. ${ }^{1 d, e)}$ 原因として, 色素合成原料に 3 種の異性体を 含む混合キシリジンが使用されたものと考えられ る. ${ }^{1 e)}$ このよjに副色素に関しての問題は必ずしも 十分解明されていないのが現状であり，副色素等の 夾雑物についての衛生化学的研究が必要と考えられ る.

一方，米国では，合成色素に関し，純色素含量は もちろん，原料・ 反応中間体・副色素含量等につい ても許容值が定められているものもあり, ${ }^{3)}$ 純色素 以外の夾雑物に対する衛生化学的な考慮がなされて いる.

以上の観点から, 著者らは市販赤色 201 号中の変 異原性夾雑物の構造解明のためには, 関連する副色 
素についての検討が必要であると考えた. Fig.1に 赤色 201 号の主原料の合成経路を示した。 2 -アミ ノ-5-メチルベンゼンスルホン酸(4)は(1)の二トロ 化・還元・スルホン化により合成されるが, ${ }^{4 a)}(4)$ 中に は主な夾雑化合物として，未スルホン化体の(3)や異 性体の(5)が考えられる.

一方，3 -ヒドロキシ-2-ナフタレンカルボン酸(10)

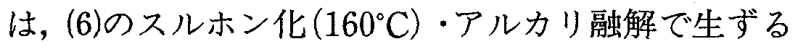
(8)のナトリウム塩(9)に, 加圧下 $240^{\circ} \mathrm{C}$ で $\mathrm{CO}_{2}$ を作用 させて得られる。ところで, $120^{\circ} \mathrm{C} て ゙(9) に \mathrm{CO}_{2}$ を作用 させると(11)を生じるが，更に加熱 $\left(145-160^{\circ} \mathrm{C}\right)$ する と $\mathrm{CO}_{2}$ を放出し(12) と(8)に分解する. ${ }^{4 b)}$ したがって, 原料(10)中に主として夾雑する化合物には(8)が考えら れる.

色素原料(4)及び(10)とそれらに主として夾雑する化 合物の組み合わせにより生成可能な副色素及び赤色 201 号の構造式を Fig. 2 に示した.

本報では，これら 5 種の副色素を合成し，HPLC 等による機器分析及び Ames 試験による変異原性 の有無を検討したので以下報告する。

\section{実 験 方 法}

1. 副色素類の合成 Fig. 2 に示した副色素 5
種と赤色 201 号をジアゾカップリング反応により合 成した。精製は，各々の色素に適した溶媒で再結晶 を 3 回繰り返して行った。

2. 機器分析 前項 1 で合成した色素につい て, 元素分析, 質量分析, 紫外・可視吸収スペクト ル測定，HPLCによる分析を行った.

1）元素分析・質量分析——試料を減圧下（5 $\mathrm{mmHg}) 80^{\circ} \mathrm{C}$ で乾燥し分析した。

2）紫外・可視吸収スペクトル測定——乾燥試料 $10 \mathrm{mg}$ をメタノール $100 \mathrm{ml}$ に溶解し原液とした. ス

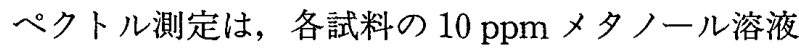
について島津 UV-260 型分光光度計を用いて行っ た.

3） HPLC 分析一一装置は日立製作所 L-4200 型検出器, 665 A-52 型カラムオーブン, D-2500 型ク ロマトインテグレーター付 L-6200 型インテリジェ ントポンプを使用した。 カラムはガスクロ工業製 Inertsil ODS $10(250 \times 4.6 \mathrm{~mm}$ i.d. $)$ を, 溶離液は アセトニトリルー水一蟻酸混液を用いた。カラム温 度は $40^{\circ} \mathrm{C}$, 検出波長は $500 \mathrm{~nm}$, 注入量は $5-20 \mu \mathrm{l}$ としグラジエント分析を行った。

3. 変異原性試験 既報 ${ }^{1 a-c, e)}$ 同様, Ames の原 報5)にプレインキュベーションを組み入れた矢作の

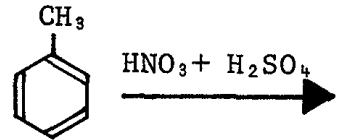

(1)<smiles>Cc1ccc([N+](=O)[O-])cc1</smiles>

(2)

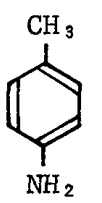

(3)

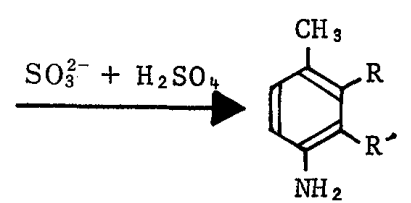

$$
\begin{array}{ll}
\mathrm{R}=\mathrm{H} & \mathrm{R}=\mathrm{SO}_{3} \mathrm{H} \\
\mathrm{R}^{-}=\mathrm{SO}_{3} \mathrm{H} & \mathrm{R}^{-}=\mathrm{H}^{-1}
\end{array}
$$

(4)

(5)

2

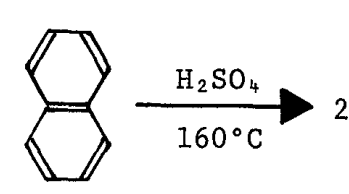

(6)

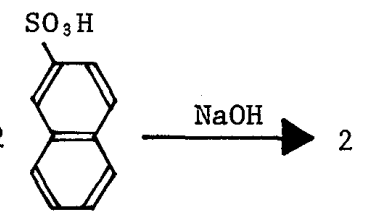

(7)

$\mathrm{NaOH}$

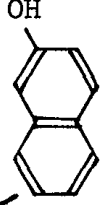

(8)

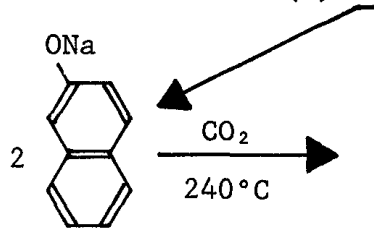

(9)
ONa COONa

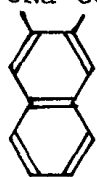

(10)

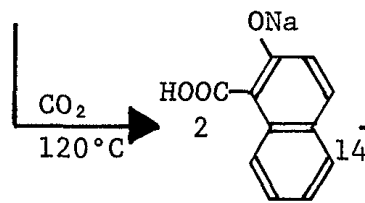

(11)

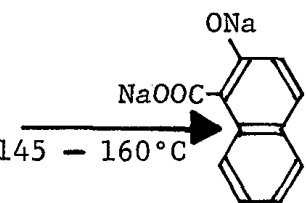

(12)
+ (8) $+\mathrm{CO}_{2}$

Fig. 1. Synthetic Processes of Starting Materials of Lithol Rubine B 


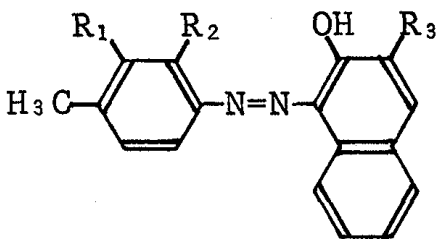

(I) : $\mathrm{R}_{1}=\mathrm{H}, \mathrm{R}_{2}=\mathrm{H}, \mathrm{R}_{3}=\mathrm{H}$.

(II) : $\mathrm{R}_{1}=\mathrm{H}, \mathrm{R}_{2}=\mathrm{SO}_{3} \mathrm{Na}, \mathrm{R}_{3}=\mathrm{H}$.

(III) : $\mathrm{R}_{1}=\mathrm{SO}_{3} \mathrm{Na}, \mathrm{R}_{2}=\mathrm{H}, \mathrm{R}_{3}=\mathrm{H}$.

(IV) : $\mathrm{R}_{1}=\mathrm{H}, \mathrm{R}_{2}=\mathrm{H}, \mathrm{R}_{3}=\mathrm{COONa}$.

(V) ${ }^{a)}: \mathrm{R}_{1}=\mathrm{H}, \mathrm{R}_{2}=\mathrm{SO}_{3} \mathrm{Na}, \mathrm{R}_{3}=\mathrm{COONa}$.

(VI) : $\mathrm{R}_{1}=\mathrm{SO}_{3} \mathrm{Na}, \mathrm{R}_{2}=\mathrm{H}, \mathrm{R}_{3}=\mathrm{COONa}$.

Fig. 2. Chemical Structures of Lithol Rubine B and Its Subsidiary Dyes

a) Lithol Rubine B (C.I. 15850).
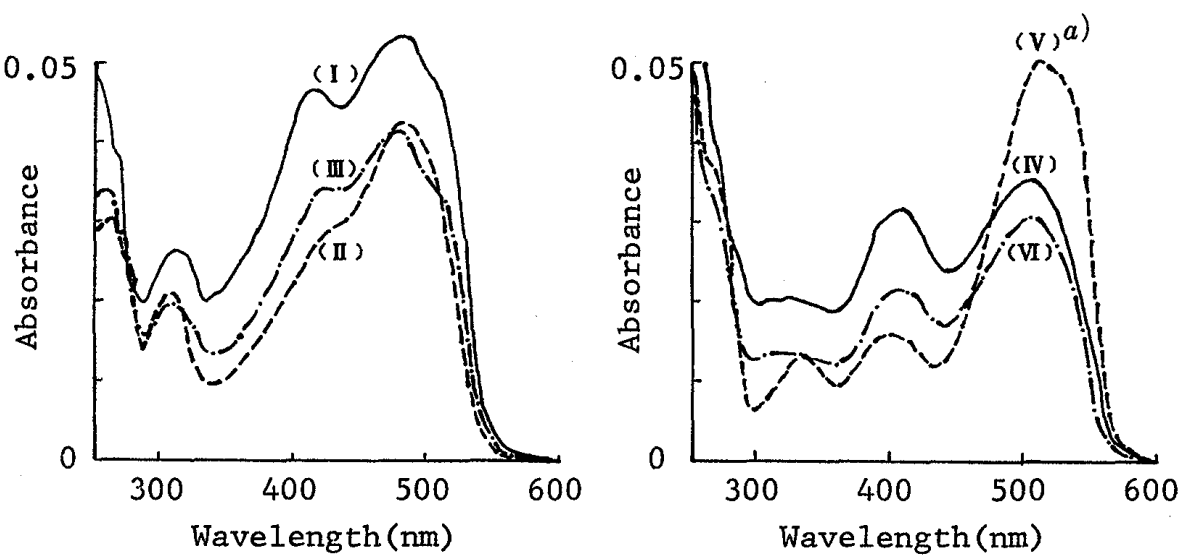

Fig. 3. Absorption Spectra of Lithol Rubine B and Its Subsidiary Dyes

a) Lithol Rubine B (C.I. 15850).

Absorption spectrum of each compound in methanol solution (10 ppm) was measured with Shimadzu UV-260 spectrophotometer. The numbers of the absorption spectra correspond to the numbers marked to the chemical structures in Fig. 2. The compound I, II and III showed the same absorption maximum in methanol $\left(\lambda_{\max }=480 \mathrm{~nm}\right)$ and their extinctions $\left(\mathrm{E}_{1}^{1 \%} \mathrm{~cm}\right)$ were 517,434 and 415 , respectively. For the other dyes (IV, V and VI), the $\lambda_{\max }$ were $510 \mathrm{~nm}$ and the $\mathrm{E}_{1}^{1} \mathrm{~cm}$ were 360,505 and 323 , respectively.

方法㬏従って行った。

\section{結 果 及び考察}

\section{1. 副色素類の元素分析・質量分析}

Table Iに元素分析の結果を示した，表中の試料 番号は Fig. 2 における各色素に付した番号で示し たが，以下の図表でも同様取り扱うことにする。元 素分析の結果，各色素ともに計算値と分析値は一致 した。一方，チャートは省略したが，質量分析の結 果からも各色素の構造を裹付けるイオンピークが得 られた。 なお，副色素の内 II はカラーインデックス 収載色素（C.I. 15590, C.I. Pigment Red 70）である
が，他の 4 種は未収載色素である。7

\section{2. 副色素類の紫外・可視吸収スペクトル}

Fig. 3 には各色素の紫外・可視吸収スペクトルを 示した. 色素 I， II 及び III（A グループ）では赤色 色素としての極大吸収波長 $\left(\lambda_{\max }\right)$ は同一の $480 \mathrm{~nm}$ であり，色素 IV，V及びVI（Bグループ）の $\lambda_{\max }$ も同一の $510 \mathrm{~nm}$ であった. A グループの構造上の 相違はスルホン基の有無及びその置換位置である が，その相違は $\lambda_{\max }$ に対して影響はなかった。同様 に，Bグループでも，その相違は $\lambda_{\max }$ に対して影響 はなかった。一方, A 及び B グループ間の構造上の 相違はカルボキシル基の有無である，Bグループ色 
素の $\lambda_{\max }$ は A グループ色素の $\lambda_{\max }$ より $30 \mathrm{~nm}$ 長波 長に移動しており，これはカルボキシル基の有無の 影響によるものと推察される。このように吸収スぺ クトル上には置換基の有無及び置換位置による影響 が規則的に反映されている.

\section{3. 副色素類の HPLC}

逆相分配カラムである Inertsil ODS カラムを用 いて色素 6 種の分離を検討した。著者らは赤色 505 号異性体の分離にZorbax ODS カラムを用い，アセ トニトリルー氷混合系を移動相とした時に最も良い 結果を得ている。 ${ }^{1 e)}$ ところで, 色素 II, III, V 及び VI （Cグループ）に比べると色素 I 及び IV（D グルー プ）はスルホン基を有して扔らず，その極性は C グ ループよりも低い．逆相分配クロマトグラフィーの 一般則に従うと, D グループの保持時間は C グルー

Table II: Gradient Profiles Employed for the Separation of Dyes

\begin{tabular}{ccc}
\hline $\begin{array}{c}\text { Time } \\
(\mathrm{min})\end{array}$ & $\begin{array}{c}\text { Flow rate } \\
(\mathrm{ml} / \mathrm{min})\end{array}$ & $\begin{array}{c}\text { \% Carrier A } \\
\text { vs carrier B }\end{array}$ \\
\hline 0 & 3.0 & 100 \\
18 & 3.0 & 100 \\
22 & 3.0 & 0 \\
28 & 3.0 & 0 \\
32 & 3.0 & 100 \\
Indefinite & 3.0 & 100 \\
\hline
\end{tabular}

a) Carrier A: acetonitrile-water $(3: 7, \mathrm{v} / \mathrm{v})$ with $0.04 \%$ formic acid, carrier $B$ : acetonitrile-water $(8.5: 1.5, \mathrm{v} / \mathrm{v})$ with $0.04 \%$ formic acid.

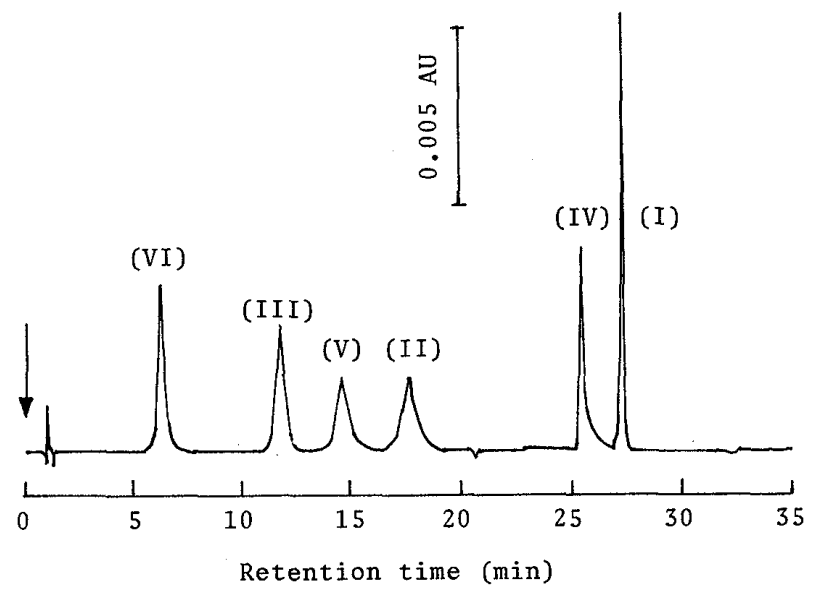

Fig. 4. HPLC Chromatogram of Lithol Rubine $B$ and Its Subsidiary Dyes

Operating conditions — column: Inertsil ODS $(250 \times 4.6$ $\mathrm{mm}$ i.d.) ; mobile phase : as shown in Table II ; detecting wavelength: $500 \mathrm{~nm}$; sample injection: about $167 \mathrm{ng}$ of dye in $10 \mu 1$ methanol; column temperature: $40^{\circ} \mathrm{C}$.
プに比べかなり長いものと推察される。これを考慮 に入れ,色素 6 種の同時分離条件を検討したところ, Inertsil ODS カラムを用い，0.04\%蟻酸を含むアセ トニトリルー水混合液 $(3: 7, \mathrm{v} / \mathrm{v})$ 及び $0.04 \%$ 蟻 酸を含むアセトニトリルー水混合液 $(8.5: 1.5, \mathrm{v} / \mathrm{v})$ を移動相 A 及び B として Table II に示したグラジ エント条件で良い結果が得られた. Fig. 4 にその時 の色素 6 種のクロマトグラムを示した.

移動相 AによるCグループの溶出順はVI> III >V >II の順であった．その順序には規則性が認 められ，メチル基の $m$ 位よりも 0 位にスルホン基 が置換した方が溶出順位は早かった（VI > V 及び III >II). また，カルボキシル基の存在も溶出順位を 早めた $(\mathrm{VI}>\mathrm{III}$ 及び $\mathrm{V}>\mathrm{II})$ 。移動相 B による D グ ループの溶出順序もカルボキシル基を有する方が早 かった (IV>I).

\section{4. 变異原性試験}

Table IIIに副色素類について変異原性試験を 行った結果を示したが，いずれの色素にも変異原性 は認められなかった。なお，色素 V (赤色 201 号) は変異原性を示さないことが確認されており, ${ }^{1 c}$ 試 験は実施しなかった。今回の結果より,市販赤色 201 号中に夾雑する変異原性物質は, これらの副色素類 ではないことが明らかになった。

今回合成した 5 種の副色素は, 赤色 201 号合成時 に比較的夾雑しやすいと考えられるものである．色 素原料合成経路（Fig. 1) から考之れば，5種以外の 副色素の生成も有り得るが，その量は極微量で変異 原性出現への奇与も非常に少ないものと考えられ る. したがって，赤色 201 号中に夾雑する変異原性 物質は，色素合成時の反応中間体に由来する可能性 の高いことが示唆された。今後は，この反応中間体 を中心に検討する必要があり, 現在赤色 201 号 (6： 5 ）酢酸エチ儿抽出物中からの変異原性物質の分離 精製について検討中である。

\section{結 論}

化粧品用赤色 201 号の副色素類の衛生化学的検討 として，HPLCによる分離条件を検討したところ， Inertsil ODS カラムとアセトニトリルー水一蟻酸系 移動相を用いるグラジエント分析により，赤色 201 号とその副色素 5 種が良好に分離した。

また，副色素の変異原性を検討したところ，いず れも変異原性は検出されず, 赤色 201 号中の変異原 性物質が 5 種の副色素と異なる構造を有することが 明らかになり，反応中間体である可能性が示唆され 
TABle III. Mutagenic Activities of Subsidiary Dyes

\begin{tabular}{|c|c|c|c|c|c|}
\hline \multirow{3}{*}{$\begin{array}{l}\text { Test } \\
\text { compound }\end{array}$} & \multirow{3}{*}{$\begin{array}{c}\text { Concentration } \\
(\mu \mathrm{g} / \text { plate })\end{array}$} & \multicolumn{4}{|c|}{ Number of $\mathrm{His}^{+}$revertants/plate } \\
\hline & & \multicolumn{2}{|c|}{ TA 98} & \multicolumn{2}{|c|}{ TA 100} \\
\hline & & $-\mathrm{S} 9^{a)}$ & $+\mathrm{S} 9^{a)}$ & - S9 & $+\mathrm{S} 9$ \\
\hline $\mathrm{DMSO}^{b)}$ & - & $36.4(15)^{c}$ & $52.3(10)$ & $121.1(15)$ & $116.3(12)$ \\
\hline \multirow[t]{3}{*}{$4 \mathrm{NQO}^{\infty}$} & 0.05 & - & - & $522.3(14)$ & - \\
\hline & 0.10 & $172.7(14)$ & - & $778.8(16)$ & - \\
\hline & 0.20 & $242.7(16)$ & - & - & - \\
\hline \multirow[t]{2}{*}{$\mathrm{B}[a] \mathrm{p}^{d)}$} & 1 & - & $87.6(11)$ & - & $179.4(12)$ \\
\hline & 2 & - & $158.1(11)$ & - & $279.1(12)$ \\
\hline \multirow[t]{4}{*}{$\mathrm{I}^{e)}$} & 1 & $34^{\text {f }}$ & 48 & 140 & 113 \\
\hline & 10 & 40 & 43 & 116 & 88 \\
\hline & 100 & 31 & 41 & 110 & 79 \\
\hline & 1000 & 28 & 49 & 130 & 75 \\
\hline \multirow[t]{4}{*}{ II } & 1 & 39 & 57 & 102 & 110 \\
\hline & 10 & 32 & 38 & 110 & 120 \\
\hline & 100 & 46 & 55 & 129 & 102 \\
\hline & 1000 & 38 & 44 & 115 & 114 \\
\hline \multirow[t]{4}{*}{ III } & 1 & 30 & 60 & 117 & 132 \\
\hline & 10 & 31 & 50 & 118 & 137 \\
\hline & 100 & 37 & 65 & 133 & 133 \\
\hline & 1000 & 42 & 41 & 135 & 125 \\
\hline \multirow[t]{4}{*}{ IV } & 1 & 32 & 44 & 124 & 82 \\
\hline & 10 & 34 & 52 & 126 & 77 \\
\hline & 100 & 38 & 40 & 107 & 68 \\
\hline & 1000 & 23 & Killing & 92 & Killing \\
\hline \multirow[t]{4}{*}{ VI } & 1 & 32 & 49 & 137 & 141 \\
\hline & 10 & 37 & 42 & 129 & 138 \\
\hline & 100 & 39 & 55 & 113 & 135 \\
\hline & 1000 & 35 & 48 & 128 & 130 \\
\hline
\end{tabular}

a) $-\mathrm{S} 9$ : without $\mathrm{S} 9 \mathrm{mix},+\mathrm{S} 9$ : with $\mathrm{S} 9 \mathrm{mix}$.

b) DMSO : solvent control.

c) Mean (number of experiments).

d) $4 \mathrm{NQO}$ : reference compound without $\mathrm{S} 9 \mathrm{mix} ; \mathrm{B}[a] \mathrm{p}$ : reference compound with $\mathrm{S} 9 \mathrm{mix}$.

e) The numbers of the test compounds correspond to the numbers marked to the chemical structures in Fig. 2 .

f) The numbers of revertant colonies are the averages of two assays.

た.

\section{引用 文 献}

1） a）宮越 護, 早川ゆみ子, 永山富雄, 衛生化学, 29, 212（1983）；b）宮越 護, 早川ゆみ子, 永田 稔, 永山富雄, ibid., 31，79(1985)；c）Idem，ibid., 33，276(1987)； $d$ ） 早川ゆみ子, 宮越 護, 小林恵美子, 永田 稔, 永山富雄, ibid., 29, 274 (1983)；e）早川ゆみ子, 宮越 護, 永山富雄, ibid., 30, 11 (1984).

2）小塚雄民，田代 実，奥村雄司，藤本圭一，中村由美，橋本誠一，中南 元，皮膚，19，191(1977); T. Kozuka, M. Tashiro, S. Sano, K. Fujimoto, Y. Nakamura, S. Hashimoto, G. Nakaminami, Contact Dermatitis, 5, 297 (1979).

3) Sidney Williams (ed.), "Official Methods of Analysis of the AOAC," 14th ed., Association of Official Analitical Chemists, Inc., Virginia, 1984, pp.639-657.

4） a）小方芳郎，増尾富士雄，小田良平，吉田善一，岡野正弥，三枝武夫，古川淳二，鶴田禎二，大西 
章, “大有機化学 9 巻, 芳香族化合物 I, ”第 1 版，小竹無二雄監修, 朝倉書店, 東京, $1958, p .486$; b) Idem, “大有機化学 11 巻, 芳香族化合物 III, ”第 1 版, 小竹無二雄監修, 朝倉書店, 東京, 1959, pp.189-195.

5) B.N. Ames, J. McCann, E. Yamasaki, Mutat. Res., 98, 101 (1975).

6）矢作多貴江，蛋白・核酸・酵素， 20, 1179 (1975).

7) "Color Index," 3rd ed., Vol. 4, ed. by the Society of Dyers and Colorists and the American Association of Textile Chemists and Colorists, Bradford and London, 1971, p.4080. 